ESJ Social Sciences

\title{
Pre-Service Science Teachers' Assessment of Supported Teaching in School
}

\author{
Isaac Sonful Coffie \\ Tutor, Wiawso College of Education, Ghana, \\ $\mathrm{Ph} . D$. student at the University of Technology Sydney \\ Nutifafa Godson Doe \\ Tutor, Wiawso College of Education, Ghana, \\ Ph.D. student at the University of Cape Coast \\ Jonah Addai Tabi \\ Tutor, Wiawso College of Education, Ghana
}

Doi:10.19044/esj.2021.v17n32p257

Submitted: 06 September 2021

Accepted: 17 September 2021

Published: 30 September 2021
Copyright 2021 Author(s)

Under Creative Commons BY-NC-ND

4.0 OPEN ACCESS

Cite As:

Coffie I.S., Doe N.G. \& Tabi J.A. (2021). Pre-Service Science Teachers' Assessment of Supported Teaching in School. European Scientific Journal, ESJ, 17 (32), 257.

https://doi.org/10.19044/esj.2021.v17n32p257

\section{Abstract}

Ghana is currently running a new teacher education program for the training of teachers at the pre-tertiary level. At the heart of the new national teacher education program is Supported Teaching in School (STS), the practical school-based component of the teacher education program embedded throughout the whole 4-years. The purpose of this study was to assess the impact of STS in pre-service teacher preparation and identify any possible challenges associated with the program. The study adopted qualitative a case study design, with the main instruments for data collection being interviews and documentary analysis. Data collection was done through individual and focus group interviews, and documentary analysis of Student Reflective Journals. Individual interviews were conducted for six pre-service science teachers and the focus group interview was made up of four pre-service teachers using the Ishikawa or fishbone tool. From the analysis of data done using "topological analysis," it was revealed that supported teaching in school is impacting on the pre-service preparation in; real classroom exposure giving them firsthand experience of the classroom situation; lesson planning and delivery; teacher professionalism as the pre-service teachers now exposed to 
traits of the teaching profession and qualities of a good teacher; and classroom management for effective lesson delivery. Particular challenges such as mentor-mentee relationship, lack of proper planning, and insufficient time for observation were identified to militate against the program. It is recommended that, appropriate training and incentives should be given to the mentors to prepare them adequately for the program.

Keywords: Pre-service teacher, field experience, teacher education, teaching practice, science

\section{Introduction}

High-quality, dedicated and professional teachers are produced by initial teacher education programs. Therefore, teacher education programs need constant scrutiny to produce well- prepared teachers (Jordan et al., 2018). Teacher education should be viewed as an applied professional qualification that requires pre-service teachers to apply the concepts and strategies they simultaneously learn about in their course work within practical settings (Transforming -Teacher Education and Learning, [T-TEL], 2018). Various researches in teacher education have indicated that, extensive field experience is a key feature of effective initial teacher education (Cochran-Smith, et al. 2016; Darling-Hammond, 2006b; Darling-Hammond, et al. 2017; Dunst, et al., 2019; Jordan et al., 2018). Such programs require a minimum of one academic year of student teaching under expert supervision and mentoring. A good quality field experience is essential for pre-service teachers to meet demands of teaching in real classroom (Adu-Yeboah, \& Kwaah, 2018).

Effective teacher education programs allow students to spend much time in the field throughout the whole program to examine and apply the concepts and ideas they are learning alongside experienced mentors who can teach effectively. Some researchers believe that the quality and extent of field experience before going to the classroom to teach affect teacher preparedness and performance (Ronfeldt, 2015, Zeichner, 2006). Studies have shown that the more students engage in field experiences, the better their teaching quality and student performance (Dunst, et al., 2019). However, in a study conducted by Spooner et al., (2008) to compare student teachers' experiences in a yearlong internship and their peers in the traditional semester long internship, it emerged that there was no difference in perceived teaching ability. However, the year-long internship students reported having better relationships with their mentors and greater knowledge of school policies and procedures.

Pre-service teachers need to experience coherence and integration between course work and the field-work (Jordan et al., 2018). The most crucial and challenging aspect of an effective teacher education program is integrating theory and practice. Darling-Hammond (2006a, p. 308) argues that "no 
amount of coursework can, by itself, counteract the powerful experiential lessons that shape what teachers actually do." It has been argued that given the novice teacher a classroom experience in field work enables them to make sense of the issues addressed in their academic work. Studies have shown that one key element of successful teacher education is early and sustained field experiences, (Zeichner, 2006; Darling-Hammond, 2006b). Many teacher education programs are now designed to embed practical experiences throughout the program. This is to enable students to be grounded in the teaching, which is essential if the pre-service teachers are to adopt learnercentered approaches to teaching. It is important that teacher education stakeholders seek strong preparation for teachers, advance knowledge about teaching and spread good practice (Darling-Hammond, 2006a).

Field experience is an essential element of pre-service teacher education (American Association of Colleges of Teacher Education [AACTE], 2010). It helps to develop the pedagogical skills of the pre-service teacher and "socialization them into the profession" (Spooner et al. 2008 p. 254). Britzman (2003) described field experience as a "time of formation and transformation" (p. 31) as much of what pre-service teachers learn about teaching and learning takes place within the field experience. Furthermore, it gives the pre-service teachers opportunities to develop, experience and understand teaching and learning. Field experience also exposes students to the complexity of the classroom where they observe and learn to teach (Santagata et al., 2007).

Field placement experience, though believed to be a feature of effective teacher preparation is not devoid of criticism. First, it is noted that novices' pre-service teaching experience is typically isolated from field placements with no corresponding support by the training institution (Grossman \& McDonald, 2008; Valencia et al., 2009). Also, few classroom teachers model pedagogy reflective of the educational principles studied during coursework, making observed practice a poor match from the teaching principles espoused by the teacher education program (Grossman \& McDonald, 2008; Valencia, 2009). Kiggundu and Nayimuli (2009) noted that field experience in teaching practice sometimes becomes demoralizing and frustrating for students. Field experience is affected by poor communication, unclear expectations between mentors, student teachers and university supervisors, and inadequate training for them (Johnson \& Napper-Woen, 2011, Hascher et al, 2004).

\section{The Context of the Study}

Studies conducted in Sub-Saharan Africa have described teacher education programs in many countries as outdated, misaligned with the school curriculum, overly theoretical and distant from school contexts (Lauwerier \& 
Akkari, 2015; Mulkeen, 2010). Even though, the Ghanaian educational system has achieved much, many issues call for the efficiency and effectiveness of the system (Ministry of Education, [MOE], 2017). For example, the 2016 National Education Assessment results showed that only 37\% and 22\% primary 4 pupils showed proficiency in literacy and numeracy, respectively (MOE, 2018). There are issues like teacher absenteeism, the poor performance of students in core subjects at both the basic and senior high level, the presence of untrained teachers in the classroom, and lack of support and resources for teachers to integrated ICT into their teaching (MOE, 2017).

Also, there are issues with initial the teacher education curriculum, such as a disconnect between the curriculum at the college and that of the basic education level as courses focused far more different than required at the basic level; the curriculum did not develop the attitudes, values, habits, and interest of the pre-service teacher; lack of a proper standard for initial teacher education as various institutions have their standard for training; no connection between theory and practical courses (MOE, 2017). These, coupled with other factors have led Ghana to adopt a new model of the teacher preparation program. Initial teacher preparation for the basic education level used to be three years where students were given a diploma certificate at the end of the program. With the new teacher education program, initial teacher preparation will take four years and students who complete the program will be given a Bachelor of Education Certificate. A new framework for the training of all teachers at the pre-tertiary level has been developed. The framework has four integrated pillars on which teacher training stands. These four pillars are Subject and Curriculum Knowledge, Literacy Studies in Ghanaian Languages, and English, Pedagogic Knowledge and Supported Teaching in School (MOE, 2017; T-TEL 2018). At the heart of this new national teacher education curriculum framework is Supported Teaching in School (STS).

STS is the practical school-based component of the teacher education program, designed to allow the pre-service teachers to observe, plan and work collaboratively with peers and mentors in the schools to understand the approaches to teaching and learning of children with diverse socio-cultural and linguistics backgrounds (T-TEL, 2018). It is designed to help the pre-service teachers to acquire and apply professional values and attitudes, knowledge, and practice so that they are competent enough to meet the National Teachers' Standards for beginning teachers (MOE, 2017). STS is represented by extended periods of school-based placement across the four years of the preservice teacher training. There are stipulated competencies to be attained at the end of each year. It is expected that pre-service teachers will spend 30\% of their training in the field constituting a total credit weighting of 48 (TEL, 2018). School-supported teaching is based on the critical teacher education 
approach where field experience is very central in teacher preparation (Zeichner \& Flessner, 2009). The critical teacher education approach provides a situated instruction whereby mentor teachers work closely with pre-service teachers (Cakcak, 2016).

Some studies in Africa and Ghana in particular have looked at the impact of field experience (specifically teaching practice) on pre-service teachers' competencies (Adu-Yeboah, 2011; Koross 2016). Most of these studies have looked at impact of the field experience undertaken within a semester or at most one year of teaching practice. This study looks at the impact of field experience undertaken by pre-service teachers within the first three years of teacher preparation thereby, providing a better picture of the extent to which the long period of field experience has impacted pre-service teacher preparation.

Teacher education programs are under constant pressure to show the effect of their particular approaches to preparation. Therefore, there is the need for empirical evidence upon which to make a case for the programs efficiency. Researchers have shifted focus from investigating entire program pathways to specific features of teacher preparation and their associated instructional quality (Ronfeldt et al., 2018). This study, therefore, seeks to investigate the impact of the STS as part of the 4-year Bachelor of Basic Education program on teacher preparation in a College of Education in Ghana.

The following research questions guided the study.

- What impact does Supported Teaching in School have on pre-service teacher preparation?

- What are the challenges in implementing Supported Teaching in Schools?

\section{Method}

\section{Research design}

The study adopted a qualitative case study design, with the main instruments for data collection being interviews and documentary analysis.

\section{Sample}

The study was undertaken in a College of Education in Ghana. The participants were the first batch of third-year pre-service science teachers who had experienced at least five semesters of field experience as part of their professional preparation. The purposive sampling procedure was used in selecting ten of the pre-service science teachers for the data collection. These ten pre-service teachers were purposively selected because they were consistent in their attendance to the field program and were willing to participate in the study. 


\section{Instrument}

The main instrument for data collection was a semi-structured interview guide (see Appendix). The researchers prepared it to explore the impact of the STS on the pre-service teachers' professional preparation and the challenges they face in the program. The items on the interview guide, which covered the main research questions, became a baseline question for all the participants, including those in the focus groups, except in cases where there were different follow-up questions based on interviewee responses.

\section{Data collection}

Data collection was done through individual and focus group interviews, and documentary analysis. Individual interviews were conducted with six pre-service science teachers, which lasted for an average of thirty minutes. The focus group interview was made up of four pre-service teachers and lasted for one hour. The focus group interview was conducted to triangulate the individual interviews, and Student Reflective Journal (SRJ). The Ishikawa or fishbone tool was used as part of the focus group interview. Though typically used in data analysis stage, fish bone approach was used during the focus group for three main reasons. This approach was used as means of data reduction during the data collection process, to sustain interviewees' interest and to verify and clarify the information they gave (Hopkins, 2008). In the interview, fishbone was drawn on a marker board with the main question to explore written on top of it. During the interview, any point raised by the interviewee which the researchers considered as essential regarding with regard the focus question was placed on the lines of the fish bones by the second researcher. In some cases, interviewee words were recorded directly, and sometimes the researcher paraphrased the interviewee's word, and with their consent, recorded them into the lines of the fishbone (See fig. 1) 


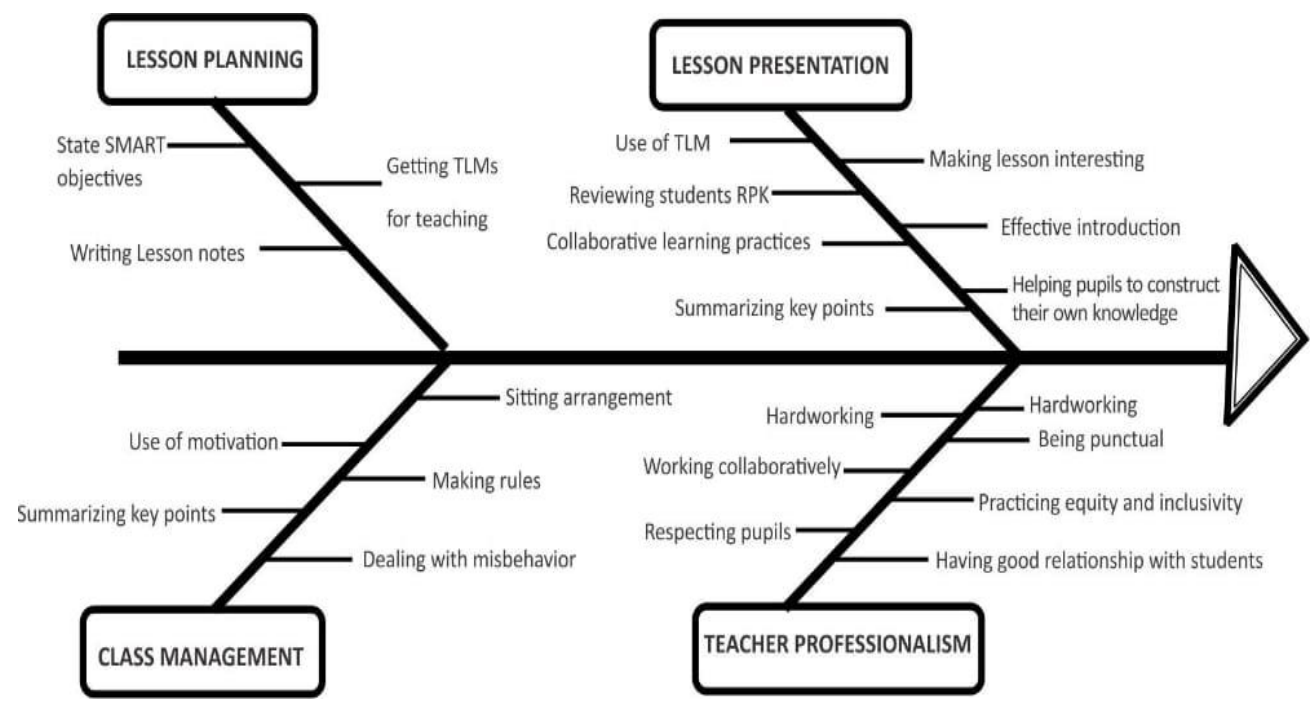

Fig.1 A fishbone developed on the impact of STS during the focus group interview

\section{Data analysis}

The data recorded during interviews were transcribed verbatim and analyzed to together with data from Students Reflective Journals "using typological analysis" (Hatch, 2002). The process began by dividing the overall data set based on initial typologies developed by researchers based on the literature. The researchers read the data and ideas that related to the generated typologies were marked. The typological entries were identified, and the main ideas of the entries were recorded on a summary sheet. The data were read and coded according to the patterns identified. Summaries were generated for each respondent, which was then developed into themes.

\section{Results and Discussion}

This section of the research presents the results and discussion by looking at the impact of the STS on pre-service teacher preparation in real classroom exposure, lesson planning and delivery, teacher professionalism, and classroom management. It further presents and discusses challenges such as mentor-mentee relationship, lack of proper planning, and insufficient time for observation which were identified to militate against the program.

\section{Impact of STS}

\section{Teacher Professionalism}

The result from the data analysis indicates that the STS program has exposed the pre-service teachers to traits of the teaching profession and qualities of a good teacher. From the data gathered from both the interview and the SRJ, it could be seen that pre-service teachers have been exposed to teacher professional traits. During the interview, a pre-service teacher 
indicated that "I have learnt professional traits like punctuality, hardworking, tolerance and respect for the pupils. I have also learnt how to be gender responsive to allow for equal opportunities for both sexes in class." Another person also indicated "I have learnt about qualities of good teaching which is being open to all students and taking their background into consideration during lesson delivery." These are clear indications that STS is making an impact and achieving its intended objectives of letting pre-service teachers identify the traits of the teaching profession and qualities of a good teacher and analyze the needs of children by considering issues of background and experience (T-Tel, 2018).

It was shown that through the program, students are learning how to work collaboratively. Pre-service teachers learn to do this by working as small groups to reflect and discuss their observations. A pre-service teacher indicated in his SRJ, "through the field experience, I have learnt how to collaborate with my colleagues to plan and deliver a lesson." The collaborative working is not only among pre-service teachers but it does occur between them and their mentors. During the interview, a pre-service teacher indicated that "I had opportunity to sit down and work with my mentor to plan and deliver a lesson. It exposed me to so many things that I should do and should not do as teacher. Working collaboratively is one of the key skills preservice teachers are expected to develop from their beginning teaching (TTEL, 2018).

One important professional trait that is being developed in the preservice teachers is reflection. Pre-service teachers have to reflect on whatever happens during their STS in their SRJ and the lessons they learn. One preservice teacher wrote in his SRJ "I had firsthand experience of standing in front students to deliver a lesson, where during the reflection with my mentor, she pointed out so many things for me to learn." Another one also indicated in the interview that "I have learnt from the STS how to reflect on a lesson taught to see its effectiveness or otherwise and if there is the need to make some modification or re-teach to the topic." Reflection is one of the key professional attitudes and values that teacher especially pre-service teachers are expected to develop in order to meet the requirement of the National Teachers Standard. Therefore, it can be stated that the STS is helping in that direction.

\section{Practical exposure}

The program has exposed the pre-service teachers to real classroom practices giving them firsthand experience of the classroom situation. It is giving the pre-service teacher practical experience as part of their professional training. This is clearly stated in what an interviewee said; 
we get so much exposure to classroom realities than we receive from college teaching which is good for us because it gives us chance to experience the practical aspect of our training... it gives us opportunity to observe how children learn, ask and answer questions and how they behave in class.

Field experience exposes students to the complexity of the classroom where they observe and learn to teach (Santagata et al., 2007). Such exposure can serve as a reinforcement of the theory the pre-service teachers are learning at the college as they come to campus with some the challenges they meet and develop possible strategies to address them (Buabeng et al., 2020). It is believed that for teacher education to function effectively in Ghana, there is the need to develop a proper linkage between theory and practice with emphasis on long practice in schools (Anamuah-Mensah, 2006).

\section{Lesson planning and delivering}

Planning and delivering a lesson is another area that our data suggest that program is making impact on the pre-service professional preparation. The pre-service teachers indicated how they have learnt effective lesson introduction and closure through the STS. On lesson planning one pre-service teacher had this to say in the interview "the STS has open my eyes on the need for effective preparation before delivering a lesson." The results indicate that pre-service teachers have had experience about different style of lesson delivery. A pre-service teacher talked about the benefit of STS in terms of lesson delivery this I way.

The field experience has opened my eyes to a lot of things like lesson preparation, introduction of lesson and making lesson interesting...I have learnt from the field experience that as a teacher, I am not boss of all knowledge, rather I should help my students to construct their own knowledge.

This implies that the supported teaching in schools is helping in achieving some of the aims envisioned in the national teacher education curriculum framework, which is that teacher will see learners as constructors of their own knowledge and thereby provide them with the needed support (MOE, 2017). The program has provided pre-service teachers with opportunity to learn to pay attention to student questions and is helping them to build their confidence as professional teachers. A pre-service teacher wrote in her SRJ "I have learnt that as teacher you have to be tolerant with your students especially their view" 


\section{Classroom management}

Pre-service teachers indicated how the program has helped them to know about classroom management for effective lesson delivery. A preservice teacher revealed how she had learnt the ways teachers use motivation and different strategies to manage their classrooms. Another pre-service teacher also said during the interview that "the STS has exposed us to classroom challenges that we are likely to face and how to manage them when we go out as trained teachers",

Management of the learning environment is one of the key aspect of the professional practice that pre-service teachers expected to develop in order the meet the National Teachers' Standard. Teachers are expected to make their classroom safe and encouraging for learning. The National Teachers' Standard require all teachers to be able to develop strategies to manage students' behaviour and learning in both large and small classes.

\section{Challenges in STS}

\section{Mentor- mentee relationship}

One major challenge facing the implementation of the STS from our data analysis has to do with the mentors' attitude toward the pre-service teachers and the program in general. It emerged that there is lack of cooperation from some of the mentors as they showed unwelcoming attitude toward the mentees. The pre-service teachers attributed this to the fact the some of the mentors expect some financial benefit for the mentorship program which they are not getting hence their lack of cooperation. They accused some of the mentors of extorting money from them. One pre-service teacher indicated in the interview that "some mentors sometimes compel us to pay money to them before they assist us especially when it comes to the filling of our assessment forms." The National teacher education curriculum framework, the policy documents that serves as basis for training teachers in Ghana at the pre-tertiary level, calls for teachers in the STS partnership schools to be given "appropriate incentive" (MOE, 2017). It could be possible that these mentors are not receiving the "appropriate incentives" and that could be reason why some mentors are not being cooperative and demanding money from students. Although the pre-service teachers attributed the uncooperative attitude of some of their mentors to lack of financial benefits, it could also be possible that the mentors are overburdened by the number of mentees they have to supervised since some mentors can receive as high as 12 pre-service teachers as mentees. This definitely could lead to their uncooperative behaviour.

It also appears that some of the mentors do not show professionalism for the pre-service teachers to emulate. A pre-service teacher complained bitterly about this situation during the interview by indicating "we were 
looking at how to prepare lesson note ... and if my mentor tells me that for me the lesson notes I do not prepare one myself let alone assisting you.... I have been discouraged till now". It appears that some of these mentors are not prepared to help pre-service teachers. The reason could be that some of them have not received the special training mandated by the National Teacher Education and Curriculum Framework to provide good mentorship for the preservice teachers. Buabeng et al. (2020) in discussing the teacher education policies and practices in Ghana, touched on these issues where they advised on the need for careful selection of schools with qualified teachers for the mentorship program, given the fact the most of the schools are poorly resourced with inadequate trained staff. They called for proper in-service training to be given to those mentors to ensure that mentorship and support they provide for the pre-service teachers will reinforce what they get at the college. They argued that if this is not done, the program will be counterproductive which is what is revealed in our findings. They further questioned the school and mentors' selection process as there is no official policy to guide the process.

\section{Lack of proper planning}

From the results, another area of challenge for the STS implementation is planning. The pre-service teachers complained about lack of proper orientation for them to be aware of what to do when they visit the school. The lack of proper orientation somehow applies to the mentors as well. A preservice teacher during the interview indicated "...because we are not properly oriented, we have to figure out what to do in the schools on our own... and our mentors also sometimes do not know how to help us." Without proper orientation of what pre-service teachers are to do and how mentors are to support them, the program will not be effective.

The students also indicated that sometimes they have to walk to their assigned schools for observation which demotivates them. One negative impact which was revealed in the research is that the STS is affecting the academic work of the pre-service teachers. They complained that anytime they go for STS they find it difficult to learn when they return to campus because they become too exhausted. Giving that some of the pre-service teachers will have to walk and some will have to sit in buses for hours before getting to their assigned schools and back, it is not surprising that they complain of tiredness. The reason why they have to travel long distance could be that the schools which are close to the college may not be enough or the number of qualified mentors in the nearby schools may not be adequate to contain all the number of students within the colleges' catchment area. This issue has been noted by Buabeng et al. (2020) who cautioned on the need to ensure that STS does not affect teaching and learning. 


\section{Insufficient time for observation}

From the results, it was noted that insufficient time for observation and irregular visits affect the benefits pre-service teachers are supposed to derive from the program. Some of the schools attached for the STS observation are far from the college and students have to sit in buses for long time before reaching their destination by which time classes might have started. During the interview, a pre-service teacher complained about this by saying "sometimes, by the time we get to our designated schools, our mentors might have finish their lessons and we have nothing to observe." The results from the data collected also indicated that there are times in which the visits to the school become irregular and not meet the required number of visits for the semester. The pre-service teachers complained about this challenge. One indicated during the interview that "we sometimes get as low as two visits for the semester which doesn't give us enough exposure to the real practice".

Pre-service teachers are expected to spend six weeks per semester (one day per week) for school observation. It is expected that the pre-service teachers will be in the school for the whole school duration from morning to afternoon observing all activities in the school. But due to factors identified in the findings such long distances between the college and partner school, students are not able stay in the school for the whole period which does not give them enough exposure to some of the school activities. The issue of not meeting the required number of visits for the semester could be just a recent phenomenon due to the impact of the COVID-19. Due to the COVID-19 situation, the Colleges in Ghana are using blended (using both online and face to face) approaches to deliver the curriculum. Because of that, students spend part of their semester online and the other part on campus, making it difficult to achieve the required number of visits to the school. Another reason for not meeting the required number of visits could also be due to non-alignment of the academic calendar of the basic schools with that of the colleges as a result of the COVID-19, so while pre-service teachers may-be school in which they can go for their STS, the basic schools may also be on vacation.

\section{Conclusion}

Given the limited empirical research about the impact of long period of field experience on pre-service teacher preparation, the study contributes to filling this important gap in literature. The study has identified that, Supported Teaching in School is making an impact on pre-service preparation in; real classroom exposure giving them firsthand experience of the classroom situation; lesson planning and delivery; teacher professionalism as the preservice teachers exposed to traits of the teaching profession and qualities of a good teacher; and classroom management for effective lesson delivery. Certain challenges such as mentor-mentee relationship, lack of proper 
planning, and insufficient time for observation were also identified to militate against the program.

The ability of beginning teachers to meet the National Teachers' Standard is mostly through the supported teaching in school and depends on a-well-prepared mentors (MOE, 2017). This implies that without well prepared and committed mentors, the dream of preparing pre-service teachers who will be able to "teach, assess, motivate, and extend the learning of all children, taking account of and respecting their backgrounds and regardless of age, aptitude, and ability (MOE, 2017, p.32) cannot be materialized.

\section{Recommendation}

From the analysis of the results, it is recommended that appropriate training and incentives should be given to the mentors to prepare them adequately for the program. The college should identify and train nearby teachers who can provide mentorship to avoid the pre-service teachers having to travel long distances. This will allow them to have enough time to observe all school activities when they visit. It is further recommended that preservice teachers be properly oriented to know what to do when going on STS.

\section{Limitations of the study}

One limitation of the study is that it focuses on pre-service science teachers in a particular college with small sample size which cannot be used for any generalization.

\section{References:}

1. Adu-Yeboah, C. \& Kwaah, C.Y. (2018). Preparing teacher trainees for field experience: Lessons from the on-campus pratical experience in colleges of education in Ghana. Sage Open, 1-18.

2. Adu-Yeboah, C. (2011). Inside the black box of learning to teach primary English and maths in Kenya and Ghana. Paper presented at the 55th Annual Conference of the Comparative and International Education Society (CIES), Montreal, Québec,Canada.

3. Association of Colleges of Teacher Education. (2010). 21st century knowledge and skills in educator preparation. Washington, DC:

4. Anamuah-Mensah, J.(2006) Teacher Education in Ghana: Theory and Practice. In K.T. Raheem, P. Kupari and Lasonen (Ed.) Educational issues for sustainable development in African. Institute for Educational Research.

5. Britzman, D. (2003). Practice makes practice: A critical study of learning to teach. Albany, NY: State University of New York Press. 
6. Buabeng, I., Ntow, F. D., \& Otami, C. D. (2020). Teacher education in Ghana: Policies and practices. Journal of Curriculum and Teaching, 9(1), 86-95. https://doi.org/10.5430/jct.v9n1p86

7. Cakcak, T. Y. (2016). A Critical Review of Teacher Education Models, International Journal of Educational Policies. 10 (2), pp.121140.

8. Cochran-Smith, M.; Villegas, A.M.; Abrams, L.W.; Chavez-Moreno, L.C.; Mills, T.; Stern, R. (2016). Research on teacher preparation: Charting the landscape of a sprawling field. In Handbook of Research on Teaching, (5th ed); Gitomer, D.H., Bell, C.A., Eds.; American Educational Research Association: Washington, DC, USA.

9. Darling-Hammond, L .(2006a). Constructing $21^{\text {st }}$ century teacher education, Journal of Teacher education, 57(3) 300-314.

10. Darling-Hammond, L.(2006b ). Powerful Teacher Education: Lessons from Exemplary Programs; Jossey-Bass: San Francisco, CA, USA.

11. Darling-Hammond, L., Hyler, M.E.,\& Gardner, M.(2017). Effective Teacher Professional Development; Learning Policy Institute: Palo Alto, CA, USA, 2017

12. Dunst, C.J., Hamby, D. W., Howse, R. B., Wilkie, H. \& Annas, K. (2019). Metasynthesis of Pre-service Professional Preparation and Teacher Education Research Studies. Educational sciences 50(9) 1-36.

13. Grossman, P., \& McDonald, M. (2008). Back to the future: Directions for research in teaching and teacher education. American Educational Research Journal, 45(1), 184-205. doi:10.3102/0002831207312906

14. Hascher, T., Cocard, Y., \& Moser, P. (2004). Forget about theory practice is all? Student teachers' learning in practicum. Teachers and Teaching: theory and practice, 10(6), 623-637

15. Hatch, J.A. (2002). Doing qualitative research in education settings State University of New York Press, Albany,

16. Hopkins, E. A. (2008) Classroom conditions to secure enjoyment and achievement: The pupils' voice. Listening to the voice of Every child matters. Education 3-13, 36(4), 393-401. To: https://doi.org/10.1080/03004270801969386

17. Johnson, I. L. \& Napper-Woen, G. (2011). The importance of role perceptions in the student teacher triad. Physical Educator, 68(1), 4456.

18. Jordan, W. J., Kuriloff, P., Sutherland, D., Pennock, A. \& Hoffman, B. (2018). Teacher preparation and quality: The role of pre-service experience and school context in urban classrooms, Temple University. 
19. Kiggundu, E \& Nayimuli, S. (2009). Teaching practice: A make or break phase for student teachers. South Africa Journal of Education, 29(8), 345-358.

20. Koross, R. (2016). The Student Teachers' Experiences during Teaching Practice and Its Impact on their Perception of the Teaching Profession. IRA International Journal of Education and Multidisciplinary Studies 5(2), 76-85.

21. Lauwerier, T., \& Akkari, A. (2015). Teachers and the quality of basic education in Sub-Saharan Africa (ERF Working Papers Series No. 11). Paris, France: UNESCO Education Research and Foresight.

22. Ministry of Education (2018). National pre-tertiary education curriculum framework: Author

23. Ministry of Education. (2017). National teacher education curriculum framework: The essential elements of initial teacher education: Author

24. Mulkeen, A. (2010). Teachers in Anglophone Africa: Issues in teacher supply, training, and management. Washington, DC: The World Bank. doi:10.1596/978-0-8213-8053-6.

25. Ronfeldt, M. (2015). Field placement schools and instructional effectiveness. Journal of Teacher Education, 66(4), 304-320

26. Ronfeldt, M., Matsko, K.K., Greene Nolan, H., \& Reininger, M. (2018). Who Knows if our Teachers are Prepared? Three Different Perspectives on Graduates' Instructional Readiness and the Features of Pre-service Preparation that Predict them. CEPA Working Paper No.18-01. http://cepa.stanford.edu/wp18-01.

27. Santagata, R., Zannoni, C. \& Stigler, J. W. (2007). The role of lesson analysis in pre-service teacher education: an empirical investigation of teacher learning from a virtual video-based field experience. Journal of Mathematics Teacher Education, 10, 123-140.

28. Spooner, M., Flowers, C., Lambert, R., \& Algozzine, B. (2008). Is more really better? Examining perceived benefits of an extended student teaching experience. The Clearing House, 81(6), 263-269.

29. Transforming Teacher education and Learning, T-TEL (2018). Professional development programme: Four- year bachelor of education degree supported teaching in school, School Placement handbook. Ministry of Education.

30. Valencia, S. W., Martin, S. D., Place, N. a., \& Grossman, P. (2009). Complex interactions in student teaching: Lost opportunities for learning. Journal of Teacher Education, 60(3), 304-322. doi:10.1177/0022487109336543.

31. Zeichner, K. (2006). Reflections of a university-based teacher educator on the future of college and university-based teacher education. Journal of Teacher Education, 57(3), 326-340. 
32. Zeichner, K. M. \& Flessner, R. (2009). Educating teachers for social justice. K. Zeichner (Ed.) Teacher education and the struggle for social justice (s. 24-43). New York: Routledge.

\section{Appendix}

\section{Interview guide}

1. Can you please share with us some of your experiences in the STS?

2. What are some of the benefits you have derived from the STS as far as your professional training is concern?

3. What are some of the challenges you face in the STS program? 